\title{
WATER RESOURCE SCARCITY AND ITS IMPACT ON MASSES IN BUNDELKHAND REGION: A CASE STUDY OF MAHOBA DISTRICT (U.P.) INDIA
}

\author{
Devendra Singh Yadav ${ }^{1}$ and G.S. Chauhan ${ }^{2}$ \\ ${ }^{1}$ Research Scholar, Department of Geography, M.L.B. Government College of Excellence \\ (Jiwaji University), Gwalior (M.P.), India \\ ${ }^{2}$ Former Head, Department of Geography, Dr. B.R. Ambedkar College, Delhi, India \\ Email: devyadavgis@gmail.com
}

\begin{abstract}
Water deficient areas, especially where geographically lesser availability of water resources in the form of Ground Water and Surface Water, constitutes major part in the fulfillment of water need of the people's daily life. Acute scarcity of water resource in the past few years due to both natural and manmade factors in the Bundelkhand Region had drawn a very thin line by imposing problems like drinking water, water for household needs, water for agro-activities and large scale mining and other means of activities has integrated these problems further to the population base of Mahoba District. These problems has made its impact on the various sections of the society in different way; where females have to make arrangements for drinking and household water needs and for this they devote a long period ; whereas the males make sure for the economic needs of the family and for this they have to relocate themselves from farm activities to industrial laborers in nearby cities or states (making it to become) more severe trends of last 25 years, where migration activities left a large negative impact on the economic and social life standard among the population base. The females and Children are the most affected and vulnerable sector (agents) of the society showing a large-scale impact made by the water borne problems in the Study region. The present adversities of water resources are making impacts on crop and agricultural patterns, livestock population, trends of urbanization and degree of land use change which further acting as active agents of change in socio-economic development over the temporal timeline in the study region.
\end{abstract}

Key words: Mining, Fulfillment, Industrial, Migration, Land use Change

\section{Introduction}

Presently the entire study region is suffering from a lot of problems related to water. The existing water resources in the study region are extremely variable in quantity and quality. With regard to the water, the most acute and major problems of the Mahoba District are viz., water depletion, drought, water scarcity, deforestation, water erosion, declining quality and quantity. All the major problems of the whole study region have been explained considering vast deforestation, irregular climate and sparse with low-density natural vegetation and uneconomic use of land resources followed by mismanagement of water resources both ground and surface. Due to very low and erratic rainfall, non-existence of any perennial system, failure of monsoon, and potential aquifer system the problem related to water are more acute and rather grave than other problems which have occurred in the entire belt of semi-arid region where there prevails chronologically rising water table, quality and supply of water, shallow water table followed by water pollution. There is no worldwide water shortage in that capacity, however, a great many of regions and areas are incessantly having less quantity of water. Mahoba region in Uttar Pradesh was announced a 'dark zone' On 13 October 2014.The term implies up images of gloom, despair, and perhaps even death and in the study region, the case is accurate as grim because it sounds. The government demarcated some areas as Dark zones where the over-exploitation of groundwater is heightened, and where the withdrawal and usage of groundwater exceed its recharge. Mahoba district is afflicted by one of its worst water deficits in decades, moving over a quarter of its populace, emptying its reservoirs and making adversity in the livestock population. The Study region is the most water crisis-affected region in the country, accounting for 13 percent of the water scarcity-prone area of India. The problem of water is confined not only in the study area but also cover large tracts of adjoining areas also. 
However, the type and degree of water scarcity are influenced by climatologically, hydrological and environmental and local geo-morphological factors.

\section{Study Area}

The Study region (Mahoba district) extends from $25^{\circ} 01^{\prime} 30^{\prime \prime}$ to $25^{\circ} 39^{\prime} 40^{\prime \prime}$ north latitude and from $79^{\circ} 15^{\prime} 00^{\prime \prime}$ to $80^{\circ} 10^{\prime} 30^{\prime \prime}$ east longitude. It consists of an area of $3144 \mathrm{Sq} . \mathrm{km}$. and as per the 2011 census, it houses $8,75,858$ people as per the 2011 census. The area under study is situated in the southwestern part of Uttar Pradesh state. It has Hamirpur district in north, Madhya Pradesh in south, Banda and Jhansi district to the east and the west respectively. The district got bifurcated officially from Hamirpur district on February 9, 1995. Before its formation, it was under the Jhansi division but currently, it happens to be one of the districts of Chitrakoot division.

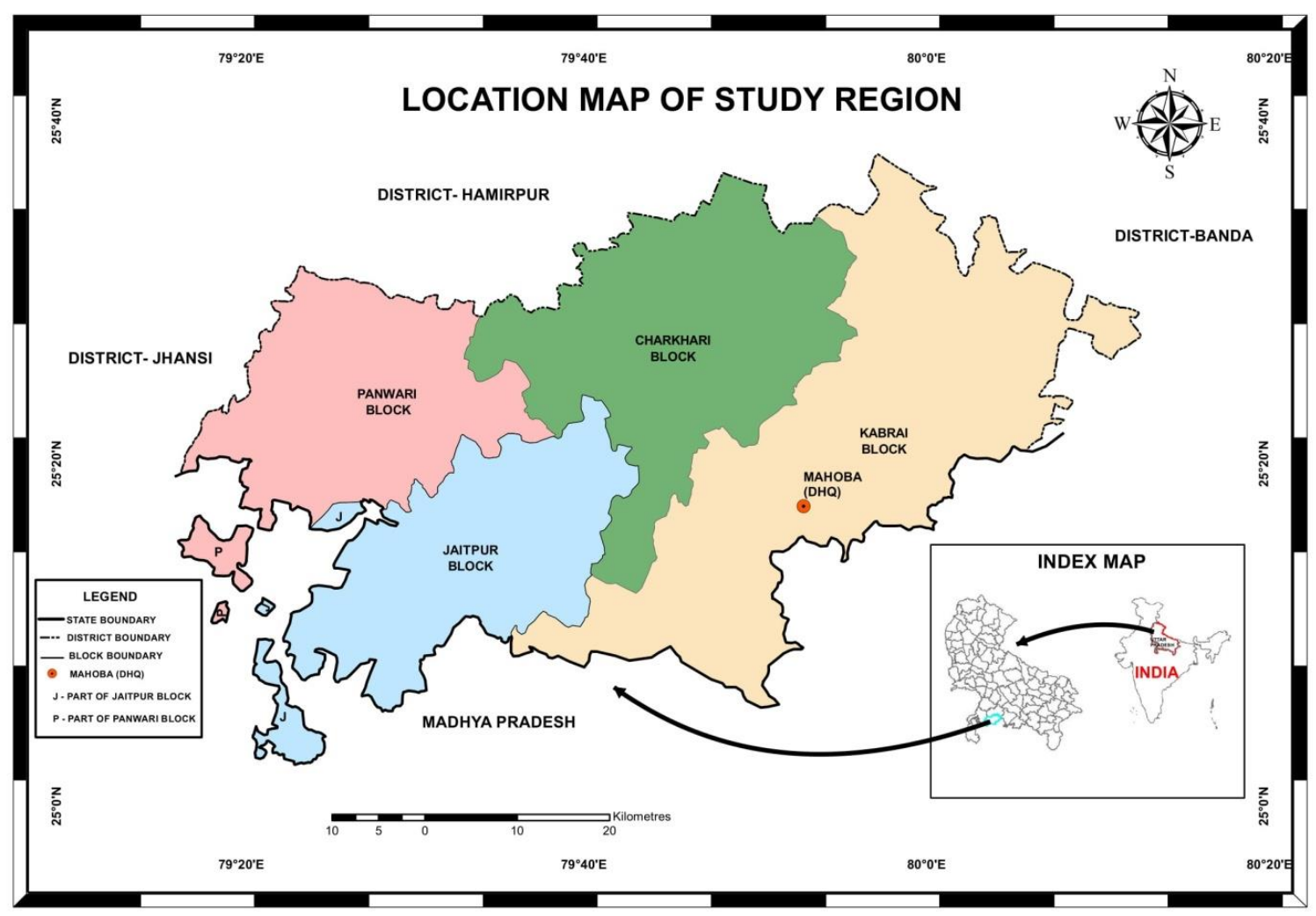

\section{Data Analysis}

The primary survey conducted in July 2019 in the four blocks (Charkhari, Jaitpur, Kabrai \& Panwari block) of Mahoba district. Throughout this area has been intensively studied through preliminary investigations conducted for selecting at least 4 villages from each block in the entire study area. On the basis of the results, the magnitude of the problem in the spatial context was determined and identified, the critical water-deficient regions worked out. This would help decision-makers and planners. The Mahoba district area was considered for the detailed research in this aspect. Four blocks are considered to be an analysis unit and 16 villages have been selected for the village level (micro) to understand the specific problems facing the region and its casual factors, having the micro-level impact in different ways.

\section{Objectives}

- To analyze and focus on the major casual factors of water scarcity.

- To asses and highlight the impact of water scarcity on various human and livestock activities.

- To know the people's perception regarding the problem of water crisis.

- To suggest the relevant strategies for the mitigation of impact water resources scarcity and its impact.

\section{Major Causal Factors for Water Scarcity}

Major causal factors for water scarcity which is found to be prevalent in almost every block of the Mahoba district of the Bundelkhand region, even with the majority number of dams in the 
study region, the queue for water earlier tap and hand pump are the usual sight throughout the summer season. In Bundelkhand, women mainly confine themselves to collect potable water on their heads from long distance.

\section{Unpredictable Monsoon and Environmental Change}

In the present $21^{\text {st }}$ Century, environmental change is a genuine worldwide challenge to solve the current water problem in the most noticeably awful manner. Improved temperature, water emergency, waterway drying and deficient storm to energize the groundwater has turned out to be one of the significant reasons for water shortage in the Mahoba area. A lack of rainstorm precipitation for two back to back years brought about serious water deficiencies in the whole region. The rainfall season a year ago got finished in September with a 24 percent rain deficit, while the deficiency in 2014 remained at 2.2 percent, as per the data of India Meteorological Department. India gets 75 percent of its yearly downpour in the rainstorm at present it is diminishing every single year. The rainfall typically spread the nation over by mid-July in the wake of coming to over the southern province of Kerala toward the beginning of June. Nearly 60 percent of the nation's farmlands are down poured and nourished.

\section{Over-Exploitation of Water Resources}

Around 50 percent of the world population depends on groundwater for drinking needs. In India, groundwater utilization is approximately to 80 percent of irrigation requirements. This has a consequence of the fast depletion of groundwater sources. Groundwater is pumped from lower and lower levels; it increased day by day and much faster than rainfall is able to recharge it. When water is overused, a shortage occurs. Too much water is being used especially for irrigation purposes. After that, it becomes inadequate for other equally use. In Mahoba, the continual creation of bore wells and hand pumps has further diminished the groundwater levels in the region. According to the Water department, this year 2017 the groundwater table has depleted by three meters. The government installed many hand pumps. The problem was not the construction of these pumps, but the fact that they were installed near wells without standard fulfill. This further caused the destruction of the wells. Because of the pumps, people stopped using the wells so the regular channels through which water would come to the well got disturbed." Construction of hand pumps in excess quantity is one of the leading cause of water contamination and depletion of groundwater tables in the study region. And yet, the administration is conveniently patting on the back. Wastage of water is also a severe reason for water scarcity. Some people run off their taps open even when they are not fetching water. The resultant problem is lack of enough water.

\section{Degradation of Forest Resources}

The people's perception regarding the land use change in several aspects of forest degradation along with the issues and problems in the study region especially with the environment. Personally visiting the study region, knowing their perception, analyzing and observing is yet another salient comprehend in understanding all such emerging issues. We can get vast knowledge, experiences and valuable ideas pertaining to the research problem by involving local residents and be able to get more and more information and facts regarding the research problem. Hence, people's perception is a vital segment of research and it can help us to solve their specific problems. Over the year of forest cover of these places started decreasing at a very high rate. An average of 25 percent of people of these blocks told that the main reason for this was the corruption done by the forest employee (Figure 1). Corruption was the main reason due to which the greenery of the place decreases, and the other reasons were an intervention of local people (24 percent), livestock (11 percent), the increment of agriculture (12 percent), land etc.

\section{Poor Planning and Leakage}

This is one of the main causes for the Mahoba District water crisis happening now as some reports state that around 20-25 percent of water is wasted due to the leakage in the pipelines. Mahoba District wastes a lot of water in the form of leakage in pumping and distribution process. New Delhi's strategies are similar to fault for the nation's unending water issues. Its appropriations and value support energize the overuse of water while it keeps on neglecting to build them across the country system expected to conserve and distribute water resource. During the field visit, it has been seen that "Site determination for check dams is impossible 
discretionarily," basically to know the absolute quantum of the progression of water at the site. According to rules, 35 percent of the all-out water must go through the check dam to keep the river lasting. The remainder of the 65 percent can be utilized". "They make their very own arrangements and execute them. There is lake is Bela Sagar in Jaitpur town. The catchment territory of this gigantic (120 ha) pond has not been infringed upon. Accordingly, the lake has flourished for centuries. "Individuals don't have the foggiest idea of how old this tank is. It never dries, even in cruel conditions.

\section{6\% MAIN CAUSES OF FOREST COVER DECREASING 2018}

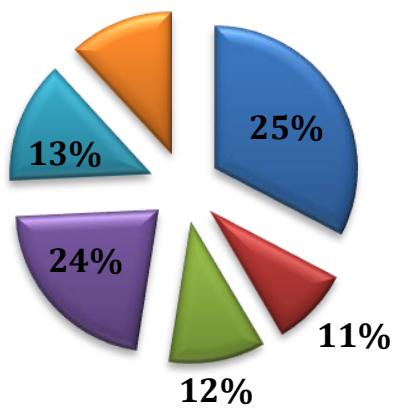

口Forest Employee Corruption

口Live Stock

$\square$ Agriculture

口Local People

$\square$ Others

$\square$ No idea

\section{Mismanagement of Water Resources}

Bundelkhand region is the most noticeably appalling place on earth for a farmer. Many years of land and water mismanagement aggravated by sickly showers and changing precipitation patterns activated by the environmental change have prompted untold hopelessness for its generally agrarian populace. In any case for the numerous network labourers and specialists, state the circumstance isn't resolving. The region may yet flourish by receiving better approaches to moderate water, in venture with progressively supportable and differing utilization of the land. As indicated by a personal visit in the study area, plainly almost 44 percent individuals believe that peppermint consumes havoc water during its cultivating. While about 20 percent of individuals stated that wheat water consumes havoc (Table 1). Since there is a great deal of deficiency of water in the area, ranchers need to believe that the harvest devouring less water ought to be liked. The significant yield in the locale devours much water thus individuals need to receive current methods of the water system with the goal that the wastage of water winds up least.

Table 01: Major Crops Consume Enormous Water in the Study Region

\begin{tabular}{|c|c|c|}
\hline$\#$ & Major Crops & Percent \\
\hline 1 & Wheat & 20 \\
\hline 2 & Pea & 17 \\
\hline 3 & Peanuts & 19 \\
\hline 4 & Peppermint & 44 \\
\hline Total $(\%)$ & & 100 \\
\hline
\end{tabular}

Source: field survey, July 2019

\section{Major Causes of Water Depletion}

Water Depletion implies a shortage or scarcity of water which implies that there is an absence of water. A shortage of water is the absence of adequate accessible freshwater resources to fulfill water needs of the local population both human \& livestock. The study region is among the least famous friendly part in India. It is ailing from water crises a lot of Ponds, lakes and underground water for the entire source has reached its minimum level. A personal survey shows that according to the view of 40 percent people in the area said that less rainfall is the real cause of water depletion. While 23.5 percent people said that deforestation is the major cause of water depletion. The rest of the people either said that various use and formation of wells and tube-wells are the major cause. This depletion of water level has now reached to a dangerous level and if proper measures are not taken then the condition of this place will become very harsh. Whereas 13.75 percent of people's perception was that increasing no. of dig wells were the main factors of surface and groundwater depletion followed by other pertinent factors. 


\section{Impact Assessment}

In any geographic zone, water is an essential part of the human, living creatures and for natural use. In many places, there might be water not far-removed as in different notified places, yet there is basically next to no resources (cash and capacity) to bring it home and makes it over the top expensive. Socio-economic implication of water scarcity plays a very important role in the study region. Water shortage is the absence of adequate accessible water resources to fulfill the needs of water utilization inside a district. The expansion in water requests is a commitment of different variables including a developing populace, expanded rural needs, and modern use and for power generation. A lot of modern toxins dumped in to the waterways are in charge of wrecking and prompting water deficiency of the entire planet. Pesticides and composts utilized in farming likewise get blended with water bodies and contaminate them. Too much use of tube wells for irrigation and utilization of bore wells for residential use additionally prompts over-misuse of underground water, diminishing the water table level bringing about water shortage. Water shortage hugely affects food production. Without water resources, people don't have methods for watering their yields and, in this manner; it will get very hard to give nourishment to the quickly developing populace. As per the International statistic, agriculture, which records for around 70 percent of worldwide water withdrawals, are continually contending with residential, industrial and ecological users for rare water supply. In endeavors to fix this consistently developing issue, many have attempted to shape progressively compelling strategies for water management.

Table 02: Block wise Major Causes of Water Depletion in the Study Region (percent)

\begin{tabular}{|c|l|c|c|c|c|c|}
\hline$\#$ & Causes & $\begin{array}{c}\text { Charkhari } \\
\text { Block }\end{array}$ & Jaitpur Block & Kabrai Block & Panwari Block & $\begin{array}{c}\text { Study } \\
\text { Region }\end{array}$ \\
\hline 1 & Dig Wells & 20 & 16 & 11 & 8 & 13.75 \\
\hline 2 & Tube-wells & 17 & 18 & 20 & 22 & 19.25 \\
\hline 3 & Less Rain fall & 34 & 41 & 43 & 42 & 40 \\
\hline 4 & Deforestation & 24 & 22 & 22 & 26 & 23.5 \\
\hline 5 & Other & 5 & 3 & 4 & 2 & 3.5 \\
\hline & Total & 100 & 100 & 100 & 100 & 100 \\
\hline
\end{tabular}

Source: field survey, July 2019

\section{Impact on Population}

The ecological impact of the water crisis is manifold including socio-economic factors, leading to migration to long distances for livelihood security. On average, about 56 percent of people in the region have travelled for more than $200 \mathrm{kms}$. It was observed during a personal field survey that most of the population of the poor strata had migrated to the neighbouring states particularly in Haryana, Delhi-NCR, Maharashtra and Gujarat for their livelihood. In the same reference, the common perception of the maximum respondents among the human population, the main sufferers were women and the headmen (earning members) of the families. They had to feed their children and face financial and food crises. Apart from all these socio-economic and biological impacts, the water crisis also brought a lot of pain and suffering to the local population and at such a critical period when contagious and non-contagious diseases spread.

\section{Education}

A large number of landless workers of Bundelkhand go to Delhi-NCR, Punjab and Haryana alongside their families during the long stretch of 'Chaita' for collecting 'Rabi' crops. Such workers are known as 'Chaitua'. This circumstance is troubling; a large number of kids in the study area are still out of schools. Further the water crisis prompts food shortage in the Bundelkhand area. 60 percent of agriculture land isn't developed because of the paucity of water for irrigation. Thus, there is a lack of food grains and the shortage of feed for creatures," said a report of the study which took criticism of over 1.40 lakh individuals. Most of farmers disclosed loss of Rabi crops and certain towns saw a 60 percent rate of migration from rural areas. Various families lost their domesticated animals' resources. The shortfall of water likewise indulges dropout of youngsters from schools and Anganwadi centers. According to the survey, 52 percent of kids skipped Anganwadi centers while more than 30 percent of youngsters left school. Mostly girls leave their school to bring water for their families in the village of study area. Even learning environment in the schools for both students and teachers was affected due to lack of drinking water amenities. 


\section{Declining of Drinking Water}

Different posts of the nation are reeling under extreme drought and a water crisis. The information additionally uncovers that the circumstance is deteriorating continuously. The per capita water accessibility in the Country has descended 70 percent from 1951 to 2011, in a range of 60 years. While the development of populace is one reason for this, the over-misuse of groundwater combined with the absence of collecting is exacerbating the situation. India is home to 63.4 million country individuals without access to clean water, the most astounding on the planet. Country populaces in poor and topographically separated territories face specific difficulties as far as getting to clean water. Also, outrageous climate occasions and environmental change make such difficulties progressively intense. In spite of being one of the world's quickest developing economies, guaranteeing water security for its developing populace is one of the principal difficulties confronting the nation. The battle of defenseless rustic networks to access clean water in Bundelkhand and investigate how improving access to water, sanitation and cleanliness administrations can transform them. There are many waterborne ailments that Individuals cease to exist. Water infection water shortage in water additionally implies sewage does not stream, and mosquitoes are different creepy crawlies breed on still (dormant) dirty water.

Table 03: Major Impact of Water Scarcity in Last decade (percent)

\begin{tabular}{|c|l|c|c|c|c|c|}
\hline \# & \multicolumn{1}{|c|}{ Impact } & $\begin{array}{c}\text { Charkhari } \\
\text { Block }\end{array}$ & $\begin{array}{c}\text { Jaitpur } \\
\text { Block }\end{array}$ & $\begin{array}{c}\text { Kabrai } \\
\text { Block }\end{array}$ & $\begin{array}{c}\text { Panwari } \\
\text { Block }\end{array}$ & $\begin{array}{c}\text { Study } \\
\text { Region }\end{array}$ \\
\hline 1 & Drinking Water & 12 & 14 & 10 & 13 & 12.25 \\
\hline 2 & Health & 5 & 7 & 4 & 5 & 5.25 \\
\hline 3 & Education & 15 & 13 & 16 & 14 & 14.5 \\
\hline 4 & Devaluation of Social Values & 16 & 18 & 20 & 21 & 18.75 \\
\hline 5 & $\begin{array}{l}\text { Disengagement of Women } \\
\text { From the workforce }\end{array}$ & 31 & 29 & 32 & 27 & 29.75 \\
\hline 6 & Migration & 21 & 19 & 18 & 20 & 19.5 \\
\hline & Total & 100 & 100 & 100 & 100 & 100 \\
\hline
\end{tabular}

Source: field survey, July 2019

\section{Disengagement of Women from the Work Force}

In Bundelkhand ladies have no work yet to gather drinking water on their heads from long distances. The horrid circumstance of water might be best remarked by one Bundelkhandi saying which generally interpreted as "let the spouse pass on yet the earthen pot of water ought not to be broken". The situation is most exceedingly poor in Mahoba district where ladies need to venture out a long distances to collect water for drinking. Half of the season of ladies is spent to fetch water, which influences their wellbeing and the prosperity of their kids.

\section{Various Losses due to Water Scarcity}

It is observed that water crisis bring immense pain and suffering not only to the local people but also to the crops, natural vegetation, livestock, water resources and living beings of the region. On the basis of a personal survey, it was found that the water crisis had left a maximum impact on the livestock. During the water crisis, the livestock particularly cows, goats, sheep and buffalos die on a large scale during the drought period due to bad quality of drinking water and the shortage of fodder etc. The second shortcoming is water crisis in agriculture according to the respondents' view. The other shortcomings victims of the water crisis are livelihood and property resources. According to the respondents the natural water crisis had a great impact on almost all walks of life. It leaves their footprints of all sorts of activities and developmental programmes. Water scarcity has led to a lot of problems for the livelihood of Bundelkhand. Many people lost their crops, livestock's and migrated to other places and sold their properties. According to the personal survey an average 37 percent of people lost their livestock, 39 percent of people have lost their crops and 12 percent of people lost own properties as well. This is a major problem and govt. should take immediate necessary steps on the ground so that these people would get relief. 
Various Losses due to Water Scarcity in Last 10 Years

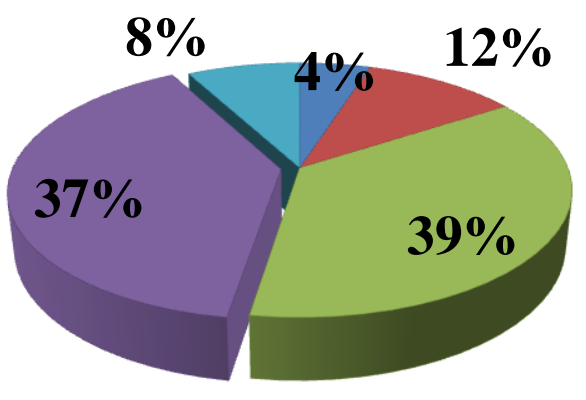

$\square$ Family

$\square$ Properties

$\square$ crops

Livestock

No loss

\section{Conclusion}

Since long, the Bundelkhand region is known as the water deficit region and it is very susceptible to water shortages and social conflicts. In the beginning, the critical areas have been delineated on the basis of the adverse production and productivity of major agricultural crops. And Socio-Economic Implications of Water Scarcity and drought are playing a major role in social and economic developmental activities. All kinds of natural life and mankind's activities are affected by water paucity. Because of water shortage, financial progress in different sectors is drastically affected in the whole study area. Without water resources, people don't have essential means for watering their yields and, in this manner, to give nourishment to the quickly developing populace. So, keeping in mind, the people's perception and suggestions of expertise regarding their specific problems, the government should instigate various programmes and policies for their settlement. Special efforts should be made to provide them water for drinking and irrigation and certain new techniques like watershed and water harvesting systems should be encouraged involving local for mass.

\section{References}

1. Brief Industrial Profile of Mahoba District, U.P. (2016) MSME-Development Institute, Kanpur (Ministry of MSME, Govt. of India), pp. 3-7.

2. Central Ground Water Board (CGWB) (2018) Ministry of Water Resources, River Development and Ganga Rejuvenation, Govt. of India, New Delhi. 15.

3. Chauhan, G. S. and Dubey, R. N. (eds.) (2004) Water Resource Management, Shri Natraj Prakashan, New Delhi.

4. Chauhan, G.S, Yadav, D.S. (2018) Dynamics of Agricultural Development: Issues and Challenges in Mahoba District of Bundelkhand Region of Uttar Pradesh "Journal of Global Resources", Volume-4(02), pp.79-88.

5. D.P.R. for I.W.M.P.6th (2016) Land Development and Water Resources Department, BSA MAHOBA III. Irrigation Management Organization, Water Management Directorate, Govt. of U.P., Lucknow.

6. District Sankhyikiya Patrika (2015-16) Economics Data and Statistics Division, Govt. of Uttar Pradesh.

7. Doubling Farmers' Income Rationale, Strategy, Prospects, and Action Plan, Policy (2017) National Institution for Transforming India (NITI), Govt. of India, New Delhi, Paper no.1/2017, pp. 3.

8. Drought Mitigation for Bundelkhand Region of Uttar Pradesh and Madhya Pradesh (2008) Report of the Inter-Ministerial Central Team, New Delhi.

9. National Environmental Policy (2006) Ministry of Environment and Forests (MoEF), Government of India.

10. National Policy on Disaster Management, (2009) National Disaster Management Authority, New Delhi, Magnum Custom Publishing.

11. National Water Policy (2012) Ministry of Water Resources, Government of India.

12. Operational Guidelines of PMKS Yojana (2018) Department of Agriculture, Cooperation \& Farmers Welfare, Ministry of Agriculture \& Farmers Welfare, Govt. of India, pp.2.

13. State Ground Water Conservation Mission, DPR for Critical Blocks Development Rain Water Harvesting and Ground Water Recharge, District Mahoba Planning Year (2017-18 to 2021-22) Department of Ground Water, Lucknow, U.P. 